\title{
Five Love Languages and Personality Factors Revisited
}

\author{
Edwin Adrianta Surijah and Komala Sari \\ School of Psychology \\ Universitas Dhyana Pura
}

\begin{abstract}
Current research replicates previous research on Five Love Languages. It aimed to gather further validation evidence and to determine whether a person with a particular love language has a certain personality type as well. Undergraduate students participated as research sample $(N=313)$. Love languages and personality types were measured with Five Love Languages scale and Big Five Inventory respectively. Zero-order correlation showed a significant correlation between love languages and personality types except on Receiving Gift and Neuroticism. Comparison with the previous research exhibited diverging result which prompts to discussions on a better approach to measuring love languages.
\end{abstract}

Keywords: five love languages, personality types, BFI, construct validity

Penelitian ini merupakan replikasi dari penelitian terdahulu mengenai lima bahasa cinta, yang bertujuan untuk memperoleh bukti kesahihan serta menentukan apakah individu dengan bahasa cinta tertentu memiliki tipe kepribadian tertentu pula. Mahasiswa dilibatkan sebagai sampel penelitian $(N=313)$. Bahasa cinta dan tipe kepribadian masing-masing diukur dengan skala Five Love Languages dan Big Five Inventory. Hasil uji korelasi zero-order menunjukkan ada hubungan yang signifikan antara kedua variabel (Asymp. Sig. > .05) kecuali aspek Receiving Gift dan Neuroticism. Perbandingan dengan penelitian sebelumnya juga belum membuahkan hasil yang kontras berbeda sehingga mendorong munculnya bahasan pendekatan yang lebih baik untuk mengukur bahasa cinta.

Kata kunci: lima bahasa cinta, tipe kepribadian, BFI, kesahihan konstruk

This study is a continuation of the language of love or known as Five Love Languages (FLL) construct validation. Surijah and Septiarly (2016) did validation study with factor analysis approach to FLL scale. The scale showed good composite reliability coefficient (.884), and item-total correlations coefficients were greater than .250 . Confirmatory factor analysis also showed the convergence of findings with the initial concept of FLL. However, the authors deleted 17 items to obtain a valid FLL scale. This is due to the results of the component analysis showed the 17 items were spread over two or more components with a low loading factor $(<.200)$.

Although the results were satisfactory, there were several previous research suggestions which can be useful to improve the understanding of the FLL construct. The first suggestion was to make a qualitative

The authors thank Yashinta Levy Septiarly for her helpful guidance with the data analysis and being our discussion partner during the refinement of the article.

Correspondence concerning this article should be addressed to Edwin A. Surijah, Universitas Dhyana Pura, Jalan Raya Padang Luwih, Badung, Bali, 80361. E-mail: edwin@ adrianta.com approach to get a more contextual language component of love. This can not be separated from the alleged influence of culture in expressing feelings that can affect the way the subject responds to the FLL scale. Another suggestion was to conduct tests with another construct to obtain other evidence of the validity of the construct and at the same time the validity of external criteria (Surijah \& Septiarly, 2016).

Another thing to consider the need for further research was the number of deleted items and the not normal data distribution (Surijah \& Septiarly, 2016). More specifically, the deleted items showed inconsistencies between the validity of the content and the result of factor analysis. Therefore, this current research is a medium to analyze whether there are differences in findings with previous research results.

Responding to previous research suggestions, the first objective of this current research is to replicate previous research. The same FLL scale is re-examined using the factor analysis method. The discussion will be based on the consistency or convergence of the obtained results. The study was also conducted 
on the same scene with previous studies by replication efforts.

The authors also seek enhancement of validity testing by conducting correlation tests on other more robust variables. The authors based this on the process of verification and validation of theories in the social sciences. Many approaches can be used in the method of validating a new theory, and one of them is the "model-to-model comparison" approach. This method validates with the "docking model" approach; comparing the data of a theoretical model with other theory models (Hahn, 2013; Macal \& North, 2007). In the context of this research, FLL as a construct or a new theory model will be compared with a more mature or steady theory model.

Axelrod (2005) wrote that replication could be seen from three levels of depth: (1) exact numerical data or results; (2) distribution of similar data; and (3) qualitatively have similarities. The "model-tomodel comparison" approach can demonstrate the validity of a theoretical construct if it is capable of fulfilling any of the three levels of depth, ranging from identical results or simply the elaboration of qualitative relationships. Therefore, in this study, the more robust variable boundary is the psychological constructs that have been studied extensively before. The selected variable is the big five personality model along with the Big Five Inventory (BFI) as the measurement tool. The big five personality model was chosen with some consideration. The first, the authors were inspired by Towler and Dipboye (2003). Their study examined the validity of the learning style by conducting a correlation test on the big five personality model. Towler and Dipboye believe that the correlation between learning styles and personality models is proof that learning styles are a valid construct. Therefore, the authors proposed a hypothesis concerning the existence of a connection between the FLL and the big five personality model. The existence of a correlation between those two variables may be taken as one of the proofs of the validity of the results of the FLL measurements, which had as their source the pattern of connections between the variables measured against other variables (AERA, APA, NCME, 2014, and the previous versions in 1999 and 1985).

Towler and Dipboye (2003) chose the big five personality model and the BFI instrument due to the view that the big five construct is robust and wellresearched. O'Connor (2002) and Boyle (2008) wrote that many researchers have sought to validate, critique, and update the dimensions of this personality model.

The big five personality model has been studied for a long time and is a most-discussed and written psychological construct (Benet-Martinez \& John, 1998; John \& Srivastava, 1999; Pervin, Cervone, \& John, 2005). This is different from the FLL that was introduced by Chapman in 1992 as a result of his findings as a marriage counselor. The first FLL-related study that the authors found appeared in 2006 by Egbert and Polk.

Among the difference between FLL and big five, these two constructs also have similarities that make them both worth comparing. Chapman (2010) believes that everyone has one of the five components of the language of love. However, from each of these components, the individual has a prominent love language called the primary love language. McCrae and Costa (as cited in Pervin, Cervone, \& John, 2005) said that a person has the five components of personality, but there is one type or factor that is dominant. This showed the equality of both constructs that epistemologically believed that all humans have personality types or love languages and there is one prominent type or factor.

FLL is a relatively new concept and not many studies performed will benefit if there is a relationship pattern with BFI. Through the "model-to-model comparison" approach, the relationship between FLL and BFI will support the criterion's validity data in addition to evidence of the construct validity.

The criterion validity is a measure of validity, determined by comparing test scores with specific performance on an external criterion. In the validation procedure based on the criteria, the test to be estimated its validity called as a predictor. The statistic used in this validation approach is the statistical correlation between the test scores distribution as a predictor and the score distribution of a relevant criterion (Azwar, 2013). For example in the context of the correlation between BFI and FLL, the validity criteria describe whether individuals with conscientiousness personality types can be predicted to have a high-quality language of love. On the opposite, whether the persons with a physical touch language of love have an openness to experience personality type.

This study is a further study that seeks to find evidence of the construct validity of the five love languages. Previous research used factor analysis as a construct validation method. Current research tested the correlation between FLL and personality type. The study with personality types may also show the criterion validity between FLL and BFI. The use of 


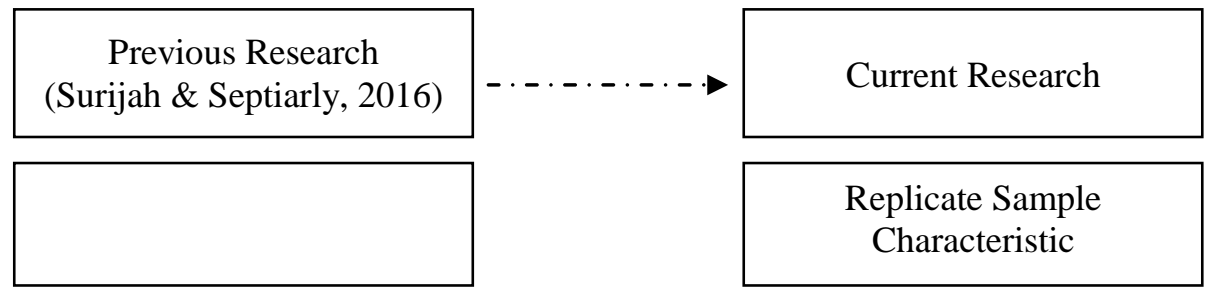

\begin{tabular}{|ll|}
\hline A. & Item-total correlation \\
& (range .261 up to .727) \\
B. & Composite Cronbach's \\
& Alpha (.884) \\
C. & Factorial Analysis (17 \\
& items retained) \\
& \\
\hline
\end{tabular}

\begin{tabular}{|l} 
A. Replicate item-total \\
correlation \\
B. Replicate Composite \\
Cronbach's Alpha \\
C. Replicate factorial \\
analysis \\
D. Correlate with \\
\\
additional model (BFI)
\end{tabular}

Figure 1. The working pattern of the effort of current replication research.

(Subjects in this study will replicate the similar scene as previous studies. The chosen analytical method also uses the same approach as previous studies. However, this study adds correlations between the FLL and BFI scales.)

the same scale and target population as previous research can help to see the consistency (reliability) of results of past and current research. The entire series of studies and their comparability to previous research can be seen in Figure 1.

\section{Five Love Languages}

Chapman (2010) stated there are five human languages of love. The five types language of love describes the difference between individuals that make them feel love. Those five types were words of affirmation, quality time, acts of service, receiving gifts, and physical touch. The previous studies (Egbert \& Polk, 2006; Surijah \& Septiarly, 2016) found that language of love consists of five components that identical by Chapman.

Cook et al. (2013) also tested the language of love construct. They found that there are five components of the love language based on factor analysis. However, there were different elements of the research results. Components of the findings of Cook et al. were: (1) sacrificial love - feeling loved when couples make sacrifices of time and energy; (2) intimate love - this aspect is a combination of physical and verbal affection; (3) quality time - similar to Chapman's early findings; (4) supportive love - contains points relating to altruism, helpful, and encouraging behavior; and (5) comforting love - the feeling of being loved when receiving assistance and attention so as to feel comfortable (physically or functionally, e.g., when being massaged, or assisted in carrying out a task).
There are at least three measurement scales to determine the type of one's love language. Chapman (2010) proposed an ipsative scale that "forces" individuals to choose one from a couple of statements that most make them feel loved. Egbert and Polk (2006) and Cook et al. (2013) each make their Likert scale for measuring FLL. In the Indonesian context, Surijah and Septiarly (2016) compiled 34 points in the Indonesian language.

The current study investigated the FLL scale in the Indonesian language. According to Surijah and Septiarly (2016), the scale in each component has an item-total correlation range $>.261$. The coefficient of the scale with the composite score was $\alpha=$ .884. The result of factor analysis by Principal Component Analysis (PCA) extraction method with Varimax rotation technique yield five components with Eigenvalue between 5.108 to 1.003 .

\section{Big Five Personality Factors}

Big-five personality is used as an approach in psychology to see human personality through trait composed of five personality dimensions that have been formed using factor analysis. The five dimensions of personality trait are extraversion, agreeableness, conscientiousness, neuroticism, and openness to experience (Friedman \& Schustack, 2008).

Extraversion is a personality type that has characteristics such as socializing, assertive, active, and talkative. Individuals with this personality type are dynamic and optimistic individuals (Rothmann \& 


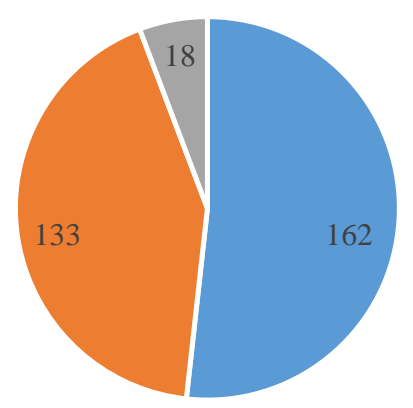

- in relationship $\quad$ ever in relationship $\quad$ never

Figure 2. Subjects' relationship history.

(Most of the subjects have a history of once or in ongoing a relationship (dating). Only 5.8\% of participants that have not dated. This condition helps the subject respond to the FLL scale asked about what makes the respondent feel loved.)

Coetzer, 2003). In general, this personality type belongs to affective or positive emotions. The opposite of the extraversion personality type is introvertsion. Unlike extraversion, individuals with this kind tend to be quiet and enjoy their own time.

The second type of personality is agreeableness. Individual characters of this kind are easy to help and are easily carried away by sympathy. People who are agreeable believe that others will also be happy to help or have a positive outlook on others. Conversely, individuals who are opposed to this personality type tend to be egocentric or selfish (Rothmann \& Coetzer, 2003).

Conscientiousness is a big five component that often associated with work performance and health. This personality type is associated with well-planned or organized behavior, self-discipline, and full of planning. Individuals with the characteristics of conscientiousness tend to have a strong will in achieving goals. Although it has a positive connotation, this personality type can also disrupt relationships with others because of the regularity and compulsion characteristics (Rothmann \& Coetzer, 2003).

Rothmann and Coetzer (2003) further wrote the fourth component of the big five is neuroticism. This component is an aspect of the big five that is categorized as a negative personality trait. Individuals with this type of personality tend to be overwhelmed with feelings of sadness, guilt, shame, and anger.

Finally, the fifth component of the big five is an openness to experience. As the name implies, individuals with this personality type are open to new experiences, looking for variety, and have an active imagination. People who got a low score on this component tend to be conservative and have a traditio- nal look or behavior (Rothmann \& Coetzer, 2003).

As a construct that has been tested its validities many times, there are some big five measuring tools commonly used. One of them is the NEO-PI-R (NEO Personality Inventory-Revised) that measures personality characteristics based on the big-five model. This scale was created 1992 by Costa and McCrae consisting of 240 items and has a good construct validity, a test-retest consistency, and a Cronbach alpha coefficient ranging from .86 to .92 (Rothmann \& Coetzer, 2003).

Another measuring tool is the Five Factors Personality Inventory (FFPI). This instrument consists of 100 items that measure the five aspects of personality although for the aspect of neuroticism used a different term, namely emotional stability. FFPI uses a Likert-scale approach with a choice of "not at all applicable" (1) and "applicable" (5) (Bakker, Van Der Zee, Lewig, \& Dollard, 2010).

The more practical big five scale was then created and consisted of only 44 items (John \& Srivastava, 1999). This scale is not only easier to administer, but it also has good validity and reliability. This scale was then adapted for research in Indonesia (Surijah $\&$ Sia, 2007). The study showed a satisfactory itemtotal correlation (>.300).

\section{Method}

\section{Participants}

This study is a further study of previous research by Surijah and Septiarly (2016). Therefore, in this study, the author seeks to get as close as possible sub- 
ject characteristics from previous research. The previous research process data 400 subjects of a college student. Four hundred subjects are then mapped based on the majors taken by the student.

To get a subject that is as similar as possible especially from the side of the scene and age group, the authors used the same students' population in the same university. The total number of students in the university is 1,681 . The calculation of the number of subjects used Sample Size Calculator 1.0.3.10 with 95\% level of confidence and 5\% confidence interval. Therefore the subject required approximately 313 persons. Like the previous research, the authors mapped the number of students in each faculty/department, then make the target proportion of the number of students required. The authors then did the distribution of questionnaires. From the questionnaires that have been filled and returned, the authors then conducted a draw to determine the questionnaire/respondent who was selected to participate in the study. This technique is called proportionate random sampling.

Demographically, what follows is the distribution of the research sample. On the basis of gender, 120 participants were male, and 193 were female. The spread of the ages of the participants was between 17 and 38 years. On the other hand, reviewed according to their relationship status, (in a relationship or not), the participants may be divided into three groups, that is, having never been in a relationship, currently in one, or having previously been in one (the proportionality of the three groups may be seen in Figure 2).

\section{Measurement}

In addition to using the study subjects as identical as possible to previous studies, the current study also used the same measuring tool used in Surijah and Septiarly (2016) research. The FLL scale consists of 34 statements with a Likert scale model. The authors tested the validity of the item-total correlations, and the analyzed the Cronbach's alpha coefficients for each component before being used as a data collection instrument. The authors went to a state university and are incidentally $(n=60)$ looking for pilot test participants who have the same age level as the subject target. The pilot test results showed that there were several items in each component that have not yet shown a satisfactory item-total correlation.

In general, the data in Table 1 shows that each aspect of FLL scale has good alpha coefficient $(\alpha>$
.500). The item-total correlation coefficient showed there were several items had a coefficient below than .200. There were possibilities that those items not related to the construct to be measured. The authors decided to continue using all 34 items with three considerations. First, the use of these 34 items allows the authors to compare the results of previous research. The researcher stands on the finding that in similar tests in previous studies, the items are valid. The second reason is the result of composite scores with formula Moizer (Azwar, 2013) showed the results .894 . The composite scores indicate that it can be used in measuring the language of love. The third consideration, the alpha value is influenced by the number of respondents who fill the scale. The researcher will re-test with a larger number of samples (> 60 individuals) and see if there is a change in the findings of the validity/itemtotal correlation.

The second scale used in this study is the Big Five Inventory scale (Surijah \& Sia, 2007). This scale was chosen because it has been tested and used previously in the Indonesian language. From the administration side, this measuring instrument was easier to use by the participants than the other big five scale.

The author tested the initial validity and found almost similar results to the FLL scale. Of the four aspects, only one component (Conscientiousness aspect) whose all items have satisfactory item-total correlations $(>.25)$. However, regarding reliability testing and observation on the value of Cronbach's alpha coefficient, each component of the Big Five Inventory has a good reliability. Extraversion and Agreeableness have a coefficient of .779 and .510. Neuroticism and Openness to Experience each produce Cronbach's alpha coefficient of .401 and .438. The highest reliability coefficient is Conscientiousness aspect (.856). The Big Five Inventory scale is also one of the scales included in the composite attribute since it is formed by a combination of several aspects. The reliability of this scale calculated on each aspect then calculated the overall reliability by using the composite score and the results of .55 was obtained.

This result resembles the findings of previous research (Surijah \& Sia, 2007) that tested the BFI scale using Cronbach's alpha coefficients. The coefficient value $(\alpha)$ in the earlier study ranged from $.558(\mathrm{O}$ penness to Experience aspect) to .840 (Extraversion aspect). The authors decided to continue to use 44 items of BFI as a data collection instrument based 
Table 1

The Preliminary Validity Test of Five Love Languages Scale

\begin{tabular}{|c|c|c|c|c|}
\hline No & Aspect & Reliability Coefficient $(\alpha)$ & Item No. & Correlation Item-Total \\
\hline \multirow[t]{8}{*}{1.} & Words of Affirmation & .674 & 1 & .337 \\
\hline & & & 5 & .231 \\
\hline & & & 9 & .223 \\
\hline & & & 16 & 398 \\
\hline & & & 22 & .459 \\
\hline & & & 26 & .557 \\
\hline & & & 31 & .306 \\
\hline & & & 33 & .449 \\
\hline \multirow[t]{7}{*}{2.} & Quality Time & .581 & 6 & .288 \\
\hline & & & 10 & 229 \\
\hline & & & 15 & .102 \\
\hline & & & 21 & 496 \\
\hline & & & 23 & .498 \\
\hline & & & 28 & .336 \\
\hline & & & 32 & 265 \\
\hline \multirow[t]{6}{*}{3.} & Acts of Service & .605 & 2 & .277 \\
\hline & & & 7 & .504 \\
\hline & & & 11 & 111 \\
\hline & & & 14 & .432 \\
\hline & & & 20 & .620 \\
\hline & & & 29 & .171 \\
\hline \multirow[t]{6}{*}{4.} & Receiving Gifts & .767 & 3 & .371 \\
\hline & & & 8 & 662 \\
\hline & & & 12 & 693 \\
\hline & & & 17 & .510 \\
\hline & & & 19 & .592 \\
\hline & & & 24 & .291 \\
\hline \multirow[t]{7}{*}{5.} & Physical Touch & 688 & 4 & 209 \\
\hline & & & 13 & 246 \\
\hline & & & 18 & .525 \\
\hline & & & 25 & .628 \\
\hline & & & 27 & 409 \\
\hline & & & 30 & .514 \\
\hline & & & 34 & .329 \\
\hline
\end{tabular}

on BFI was measuring tool that has been used and tested previously. This measuring tool will also be tested again with data obtained from the current research subjects. Also, the reliability showed consistent results in each component. This is another consideration to continue using the BFI scale as a tool of data collection in this study.

\section{Data Analysis Technique}

The data analysis technique used in this study was confronted with two kinds of choices. The first option was to categorize the subject and test the corre- lation by using the whole item (34 items) compiled from the beginning as the FLL measurement scale and being confidence for the content validity of each item that has been prepared by the FLL construct in question. The second option was to use the 17 items obtained (left over) from the factor analysis of previous research. The authors decided to use the first 34 items prepared with the content validity as consideration and supported by a good alpha coefficient in the preliminary study $(\alpha=.896)$.

To facilitate the reader's understanding of this series of research processes, the authors divide the two stages of the study. The first stage contains the re- 
Table 2

Description of Research Data

\begin{tabular}{|c|c|c|c|c|c|c|}
\hline & & & & Data I & iptor & \\
\hline & & $N$ & Mean & $S D$ & $\begin{array}{c}\text { Lowest Score } \\
\left(X_{\min }\right)\end{array}$ & $\begin{array}{c}\text { Highest Score } \\
\left(X_{\max }\right)\end{array}$ \\
\hline & Words of Affirmation & 313 & 31.17 & 4.476 & 14 & 40 \\
\hline & Quality Time & 313 & 26.08 & 4.567 & 7 & 35 \\
\hline $\begin{array}{l}\text { FLL } \\
\text { Comnonents }\end{array}$ & Act of Service & 313 & 18.77 & 2.11 & 10 & 24 \\
\hline & Receiving Gifts & 313 & 22.49 & 4.096 & 7 & 30 \\
\hline & Physical Touch & 313 & 27.29 & 4.823 & 7 & 35 \\
\hline & Extraversion & 313 & 28.06 & 5.316 & 12 & 40 \\
\hline & Agreeableness & 313 & 34.72 & 4.732 & 18 & 45 \\
\hline $\begin{array}{l}\text { BFI } \\
\text { Components }\end{array}$ & Conscientiousness & 313 & 29.39 & 5.096 & 15 & 45 \\
\hline & Neuroticism & 313 & 24.69 & 4.755 & 12 & 39 \\
\hline & Openness to Experience & 313 & 35.42 & 3.892 & 18 & 45 \\
\hline
\end{tabular}

validation testing of the FLL scale using the itemtotal correlation coefficients. Also, as a comparison, the authors will also use exploratory factor analysis testing. The result of current factor analysis then compared with the result of factor analysis test from previous research. Factor analysis is not used to determine the building blocks of FLL, but to see whether there are convergent findings from both test results.

The second stage is the correlation testing phase between FLL and BFI. The data analysis sequence begins with hypothesis testing. The first assumption testing is the normality test to check the distribution of data obtained. The second assumption testing is the linearity test from the data obtained from the FLL and BFI scale to see the linearity of the relationship of both data distribution. After satisfying both assumptions, the conclusions can be obtained by parametric statistical tests to determine the relationship between FLL and BFI.

The relationship testing was done with two strategies. The first is to test each component with the regression equation against BFI. This cannot be separated from the variable form as the output of FLL and BFI scale that are not global or whole. Operationally, both BFI and FLL do not have a total score. The second strategy is to test the zero-order correlation. The authors used the same strategy that Towler and Dipboye (2003) used when validating learning style scales against external criteria with BFI. The analysis was performed using SPSS 16.00 for Windows program.

\section{Results}

To be able to perform the test, first of all, the authors conducted a descriptive analysis of the data obtained. Table 2 shows descriptive data for measurement results of both scales.

Table 2 shows the data varies between the components of each variable. For example, the mean of the components of Words of Affirmation and Acts of Service are 31.17 and 10.70 respectively. This difference in the average and standard deviation values arises because of the number of different items in each component. Table 2 further reinforces the need for categorical samples of studies that use theoretical categorization (criterion-referenced). Theoretical categorization is constructed using the mean and standard deviations calculated from the highest and lowest values from each sample based on each aspect.

The use of this theoretical categorization is based on several considerations. The first reason is consistent with previous research (Surijah \& Septiarly, 2016). The research argues that this theoretical categorization is used because of the lack of adequate standard norms. FLL and BFI are conceptually believed to be owned by every individual. Therefore, sample categorization does not need to be done with standards that compare samples with the population.

Also, categorization using the mean and standard deviations as listed in Table 2 allows all the highmoderate-low categories to be filled. The categoryzation made based on the participant's response. Da- 
Table 3

Score Classification of FLL

\begin{tabular}{lcccccc}
\hline \multicolumn{1}{c}{ Range } & $\begin{array}{c}\text { Score } \\
\text { Classification }\end{array}$ & $\begin{array}{c}\text { Words of } \\
\text { Affirmation }\end{array}$ & $\begin{array}{c}\text { Quality } \\
\text { Time }\end{array}$ & $\begin{array}{c}\text { Acts of } \\
\text { Service }\end{array}$ & $\begin{array}{c}\text { Receiving } \\
\text { Gifts }\end{array}$ & $\begin{array}{c}\text { Physical } \\
\text { Touch }\end{array}$ \\
\hline$X \leq(\mu-1.5 \sigma)$ & Very Low & 1 & 4 & 3 & 2 & 1 \\
$(\mu-1.5 \sigma)<X \leq(\mu-0.5 \sigma)$ & Low & 1 & 17 & 17 & 21 & 17 \\
$(\mu-0.5 \sigma)<X \leq(\mu+0.5 \sigma)$ & Moderate & 57 & 66 & 72 & 74 & 50 \\
$(\mu+0.5 \sigma)<X \leq(\mu+1.5 \sigma)$ & High & 139 & 127 & 124 & 108 & 112 \\
$(\mu+1.5 \sigma)<X$ & Very High & 115 & 99 & 97 & 108 & 133 \\
\hline
\end{tabular}

Table 4

Score Classification of BFI

\begin{tabular}{|c|c|c|c|c|c|c|}
\hline Range & $\begin{array}{c}\text { Score } \\
\text { Classification }\end{array}$ & Extraversion & Agreeableness & Conscientiousness & Neuroticism & $\begin{array}{c}\text { Openness } \\
\text { to } \\
\text { Experience }\end{array}$ \\
\hline$X \leq(\mu-1.5 \sigma)$ & Very Low & 4 & 1 & 9 & 19 & 1 \\
\hline$(\mu-1.5 \sigma)<X \leq(\mu-0.5 \sigma)$ & Low & 29 & 7 & 39 & 49 & 6 \\
\hline$(\mu-0.5 \sigma)<X \leq(\mu+0.5 \sigma)$ & Moderate & 113 & 45 & 142 & 158 & 93 \\
\hline$(\mu+0.5 \sigma)<X \leq(\mu+1.5 \sigma)$ & High & 104 & 143 & 97 & 72 & 109 \\
\hline$(\mu+1.5 \sigma)<X$ & Very High & 63 & 117 & 26 & 15 & 104 \\
\hline Note. $\begin{aligned} \mu & =\frac{N t+N r}{2} \\
\sigma & =\frac{N t-N r}{6}\end{aligned}$ & $\begin{array}{l}\mu \\
\sigma \\
N t \\
N r\end{array}$ & $\begin{array}{l}\text { : theoretical mean } \\
: \text { theoretical stand } \\
: \text { maximal score of } \\
: \text { minimal score of }\end{array}$ & $\begin{array}{l}\text { d deviation } \\
\text { the scale } \\
\text { the scale }\end{array}$ & & & \\
\hline
\end{tabular}

ta analysis becomes incapable of showing which type of love language is most dominant in very high or deficient categories.

Table 3 and 4 indicate the classification of the study sample. The mean $(\mu)$ and Standard Deviation $(\sigma)$ in both tables were calculated using the number of items in each aspect and the highest/lowest values that may be obtained in each component. The number of items in question is obtained from the number of initial items on each scale; 34 items for the FLL scale and 44 items for the BFI scale.

\section{First Stage}

To get a reliable test data, the authors do a re-validation and reassess the reliability of the scale by using alpha coefficient. The nature of the current reassessment on the FLL was to compare data to make a stand toward the construct and FLL scale. The data utilized in the test this time is the data obtained from all sample research. In the discussion section, the researcher will discuss how the test validation has been passed through several testing stages.

Table 5 shows there are slight differences in findings in Table $1(n=60)$. In Table 5 , the number of respondents who filled the scale was 313 individuals.
The value of the alpha coefficient on the Quality Time aspect increased from .581 to .697. The itemtotal correlation in that aspect also increased from the first testing. For example, in item no. 15, the itemtotal correlation increases from .102 to .388 . However, there is one item that has decreased the itemtotal correlation was no. 1 (Words of Affirmation aspect). The item-total correlation values decreased from .337 to .086 .

The next step taken by the authors is to test the factor analysis. This test is emphasized to see whether there are convergent results with findings from previous studies. The following Table 6 is the results of a factor analysis test conducted on 34 items of FLL scale.

\section{Second Stage}

The second stage begins with assumption test is the normality test and relationship linearity test. Normality test is done with the aim to know whether the data of both scales are scattered according to a normal curve using Kolmogorov-Smirnov (K-S test) technique. This technique is used with consideration of the advantages of K-S tests that are unaffected by the data distribution and can be utilized for limited sam- 
ple quantities (Engmann \& Cousineau, 2011; Senger $\&$ Çelik, 2013). In the context of this research, the authors used theoretical classification. The FLL and BFI scales are also divided based on the aspects of the test construction so that the data are not taken from the overall items on the scale. This encourages the authors to use K-S test to determine the normality of data distribution. Data can be said to be normal if it has a normality test result with a significance level above $.05(p>.05)$. Normality test results are described in Table 7.

Based on Table 7, it can be seen that KolmogorovSmirnov $Z$ results obtained from each aspect for the Five Love Languages Scale have scores smaller than
.05. Similarly, the results of Kolmogorov-Smirnov $Z$ from each aspect of the Big Five Inventory Scale have scores smaller than .05 , so it can be concluded that the data of these two scales were skewed (see Figure 3). However, different findings were found in the relationship linearity test. The authors looked at the linearity of the relationship between components of the FLL to each of the BFI components by performing the ANOVA which included the linearity test (deviation from linearity).

Table 8 showed that each component has a significance level of $p>.05$ except the linearity test between pairs of physical touch - extraversion ( $p=$ .003 ) components and quality time - agreeableness

Table 5

Re-validation of FLL Scale

\begin{tabular}{|c|c|c|c|c|}
\hline$\overline{\text { No }}$ & Aspect & Reliability Coefficient $(\alpha)$ & Item No. & Correlation Item-Total \\
\hline \multirow[t]{8}{*}{1.} & Words of Affirmation & .644 & 1 & .086 \\
\hline & & & 5 & .202 \\
\hline & & & 9 & .339 \\
\hline & & & 16 & .365 \\
\hline & & & 22 & .443 \\
\hline & & & 26 & .493 \\
\hline & & & 31 & 464 \\
\hline & & & 33 & .463 \\
\hline \multirow[t]{7}{*}{2.} & Quality Time & .697 & 6 & .344 \\
\hline & & & 10 & .456 \\
\hline & & & 15 & .388 \\
\hline & & & 21 & .458 \\
\hline & & & 23 & .464 \\
\hline & & & 28 & .399 \\
\hline & & & 32 & .458 \\
\hline \multirow[t]{6}{*}{3.} & Acts of Service & .585 & 2 & .332 \\
\hline & & & 7 & .367 \\
\hline & & & 11 & .201 \\
\hline & & & 14 & .446 \\
\hline & & & 20 & .478 \\
\hline & & & 29 & .183 \\
\hline \multirow[t]{6}{*}{4.} & Receiving Gifts & .647 & 3 & 169 \\
\hline & & & 8 & .539 \\
\hline & & & 12 & .451 \\
\hline & & & 17 & .530 \\
\hline & & & 19 & .283 \\
\hline & & & 24 & .387 \\
\hline \multirow[t]{7}{*}{5.} & Physical Touch & .723 & 4 & 494 \\
\hline & & & 13 & .438 \\
\hline & & & 18 & .408 \\
\hline & & & 25 & .536 \\
\hline & & & 27 & .498 \\
\hline & & & 30 & .532 \\
\hline & & & 34 & .241 \\
\hline
\end{tabular}


Table 6

Exploratory Factor Analysis as Comparison

\begin{tabular}{|c|c|c|c|c|c|}
\hline No. & Factor & Eigen-Value & Percentage of Variance & Item No. & Loading Factor \\
\hline \multirow[t]{12}{*}{1.} & Component 1 & 4.678 & $13.758 \%$ & Woa9 & .630 \\
\hline & & & & Woa22 & .716 \\
\hline & & & & Qt10 & .539 \\
\hline & & & & Qt21 & .584 \\
\hline & & & & Qt23 & .429 \\
\hline & & & & Qt28 & .738 \\
\hline & & & & Aos11 & .272 \\
\hline & & & & Aos 14 & .608 \\
\hline & & & & $\operatorname{Rg} 24$ & .674 \\
\hline & & & & Pt4 & .431 \\
\hline & & & & Pt13 & .401 \\
\hline & & & & Pt30 & .437 \\
\hline \multirow[t]{9}{*}{2.} & Component 2 & 4.211 & $12.384 \%$ & Woa26 & .559 \\
\hline & & & & Woa31 &. .595 \\
\hline & & & & Aos 2 & .416 \\
\hline & & & & Aos7 & .534 \\
\hline & & & & Aos20 & .510 \\
\hline & & & & $\operatorname{Rg} 8$ & .786 \\
\hline & & & & $\operatorname{Rg} 12$ & .719 \\
\hline & & & & $\operatorname{Rg} 17$ & .508 \\
\hline & & & & Pt25 & .542 \\
\hline \multirow[t]{5}{*}{3.} & Component 3 & 2.724 & $8.011 \%$ & Woa16 & .563 \\
\hline & & & & Woa33 & .548 \\
\hline & & & & Qt6 & .621 \\
\hline & & & & Qt15 & .546 \\
\hline & & & & Qt32 & .504 \\
\hline \multirow[t]{5}{*}{4.} & Component 4 & 2.521 & $7.413 \%$ & Woa1 & .319 \\
\hline & & & & Aos 29 & .461 \\
\hline & & & & Pt18 & .547 \\
\hline & & & & Pt27 & .585 \\
\hline & & & & Pt34 & .516 \\
\hline \multirow[t]{3}{*}{5.} & Component 5 & 1.893 & $5.567 \%$ & Woa5 & .631 \\
\hline & & & & $\operatorname{Rg} 3$ & .666 \\
\hline & & & & $\operatorname{Rg} 19$ & .502 \\
\hline
\end{tabular}

$(p=.002)$. The significance value indicates that the combination of FLL and BFI aspect pairs has linear relationship except for the two pairs of components.

Figure 3 showed a graph of the data distribution pattern supported the findings of the normality test. This chart is obtained based on the categorization of data as outlined in Table 3. The graph shows the pattern of data distribution that does not resemble the normal curve. In general, the five aspects of FLL form a similar pattern that is squint to the left. This further illustrates the findings from the test of distribution normality in Table 7.
The authors decided to test with zero-order correlation and regression analysis. This decision is also taken considering in a regression analysis test or another parametric test, the normality of distribution of data distribution can be ignored (Norman, 2010). The result of zero-order correlation test with significance level below $.05(p<.05)$ is described in Table 8.

The result of zero-order correlation shows there is a significant correlation between FLL aspect and BFI aspect. For example, the Words of Affirmation aspect deals with aspects of BFI Extraversion, Agreeableness, and Openness to Experience. The strongest 
Table 7

Test of Normality Five Love Languages Scale and Big Five Inventory

\begin{tabular}{ccc}
\hline Scale & Aspect & Kolmogorov-Smirnov Sig. \\
\hline & Words of Affirmation & .003 \\
Five Love Languages & Quality Time & .015 \\
& Acts of Service & .000 \\
& Receiving Gifts & .000 \\
& Physical Touch & .000 \\
Big Five Inventory & Extraversion & .007 \\
& Agreeableness & .000 \\
& Conscientiousness & .002 \\
& Neuroticism & .001 \\
\hline
\end{tabular}

Table 8

Deviation from Linearity Sig. Value Between Five Love Languages and Big Five Inventory

\begin{tabular}{lccccc}
\hline & Extraversion & Agreeableness & Conscientiousness & Neuroticism & Openness to Exp. \\
\hline Words of Affirmation & .140 & .315 & .672 & .843 & .297 \\
Quality Time & .284 & .002 & .231 & .494 & .084 \\
Acts of Service & .054 & .250 & .961 & .533 & .609 \\
Receiving Gift & .480 & .434 & .130 & .986 & .609 \\
Physical Touch & .003 & .245 & .927 & .412 & .460 \\
\hline
\end{tabular}

Table 9

Zero-Order Correlation between FLL and BFI

\begin{tabular}{lccccc}
\hline \multirow{2}{*}{ FLL Aspects } & \multicolumn{5}{c}{ BFI Aspects } \\
\cline { 2 - 6 } Words of & Extraversion & Agreeableness & Conscientiousness & Neuroticism & Openness to Exp. \\
Affirmation & $.342^{*}$ & $.195^{*}$ & .108 & .025 & $.284^{*}$ \\
Quality Time & & & & & $.127^{*}$ \\
Acts of Service & .068 & $.194^{*}$ & $.174^{*}$ & .056 & $.16^{*}$ \\
Receiving Gifts & .075 & $.181^{*}$ & .061 & .063 & .035 \\
Physical Touch & .024 & .156 & .024 & .116 & $.207^{*}$ \\
\hline
\end{tabular}

Note: *Correlation is significant at the .05 level.

correlation is between Words of Affirmation and Extraversion $(r=.342)$. The Receiving Gift aspect is the only aspect that is not correlated with any aspect of BFI. On the other hand, Neuroticism aspect is not related to the aspects of FLL. Although there is a significant positive correlation, the magnitude of correlations between aspects tends to be small $(<.500)$.

Table 10 shows that aspects of FLL and BFI have correlation which can be seen from the significance level of each aspect that scores below .05 ( $p<.05)$. More specifically, Table 10 illustrates the ability of the big five personality aspects to explain each of the FLL components. For example, BFI components can predict the Words of Affirmation's love language of $\pm 19 \%$. The Words of Affirmation aspect has the highest $\mathrm{R}$ squared value $(R$ square $=.189)$. When referring to Table 10 , the personality type of a per- son is only able to estimate the individual's love language is only $<20 \%$. It can also mean $80 \%$ more other variables predict a person's love language.

\section{Discussion}

As explained earlier, the researcher will explain in advance a series of tests that have been attempted to determine the construct validity of the FLL.

This study aims to find a proof of the construct validity for the Five Love Languages theory that has been initiated by Chapman. Figure 4 showed the efforts that have been done from previous research (Surijah \& Septiarly, 2016). This means that the FLL scale has gone through validity testing by analyzing the item-total correlation coefficients and factor ana- 
Table 10

Contribution of Big Five Personality toward Five Love Languages Aspects

\begin{tabular}{lccc}
\hline Five Love Languages (Dependent Variable) & $R$ Square & $F$ & Sig. \\
\hline Words of Affirmation & .189 & 14.293 & .000 \\
Quality Time & .084 & 5.621 & .000 \\
Acts of Service & .059 & 3.835 & .002 \\
Receiving Gifts & .056 & 3.640 & .003 \\
Physical Touch & .111 & 7.675 & .000 \\
\hline
\end{tabular}

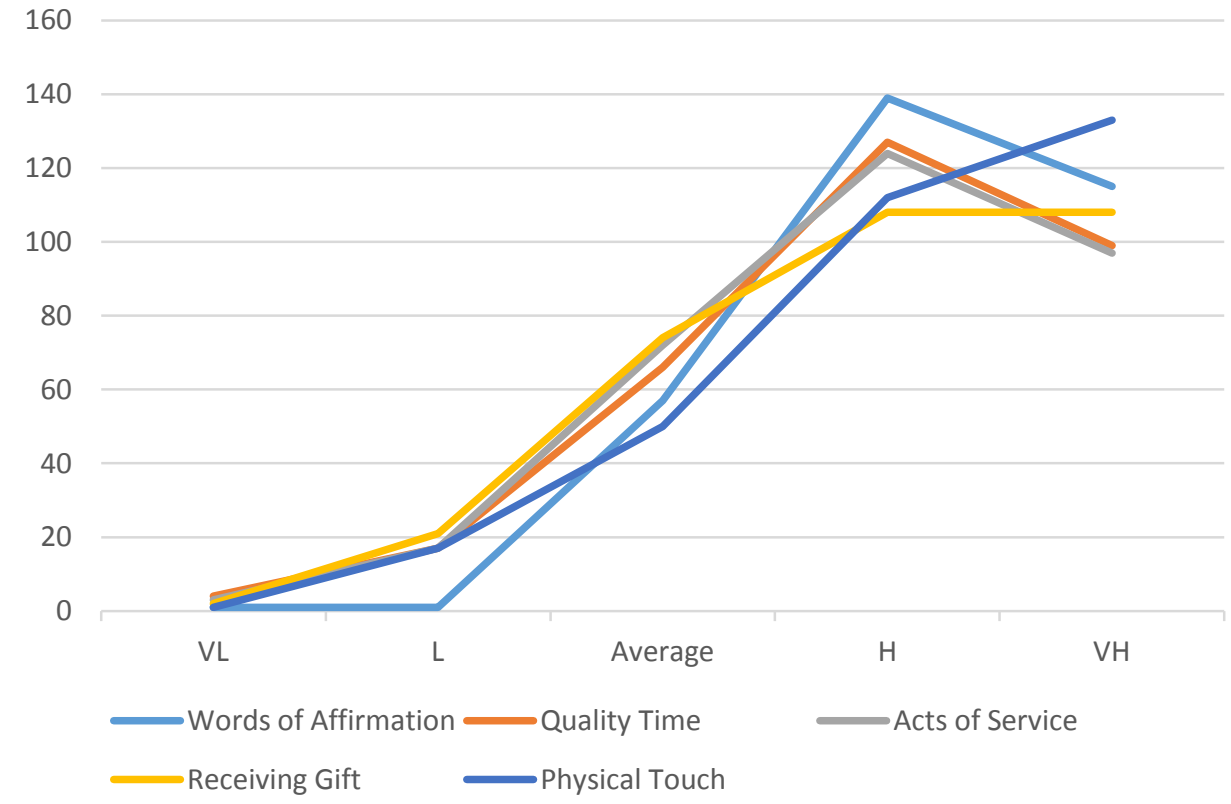

Figure 3. Data distribution on the FLL scale that does not form a normal curve.

(As an illustration, the following graph of data distribution on the FLL scale that does not form a normal curve. The $y$-axis shows the frequency of the category. The x-axis indicates categories of VL (Very Low), L (Low), Average, $\mathrm{H}$ (High), and VH (Very High).)

lysis. In the previous study, all results indicate a convergence with Chapman's initial idea. The only exceptions are the 17 deleted from the original 34 items.

In the present study, the authors replicated by performing similar tests in the same population and compared the results. At the initial testing stage and data distribution, the authors found a uniformity of findings between the two studies. However, notable differences can be seen in the results of this factor analysis. Although the results of factor analysis indicate the existence of five components of FLL compilers, each component consists of items that arranged randomly.

If the previous research, the authors (Surijah \& Septiarly, 2016) can decide to eliminate the 17 items, the test results of factor analysis in this study would encourage the authors to re-examine the instruments used. This is due to previous research; valid items also follow the initial layout/blueprint compiled (based on the validity of content). Meanwhile, in the results of this study, valid items are dispersed in different aspects or components of the original layout. This means that the authors not only need to be deleted the invalid items but also need to look carefully when using the scale.

One of the changes that can be considered is the consistent use of sentence structure. The current FLL scale has a high sentence variation. Each item has a different sentence structure (subject - predicate - object). This contrasts with the FLL scale developed by Egbert and Polk (2006) who have the same sentence structure ("I feel loved when...") and followed by a list of paired treatments. These changes are ex- 


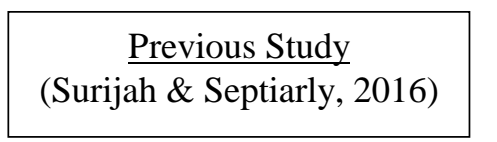

\begin{tabular}{|l|}
\hline $\begin{array}{c}\text { Construct Validity through } \\
\text { Factor Analysis } \\
\text { Results: } \\
\text { 1. }\end{array}$ \\
2. \\
Items components found \\
to blueprint/Chapman's \\
theory \\
3. Data distribution were \\
not normal \\
4. Items retained: 17 out \\
of 34 items.
\end{tabular}

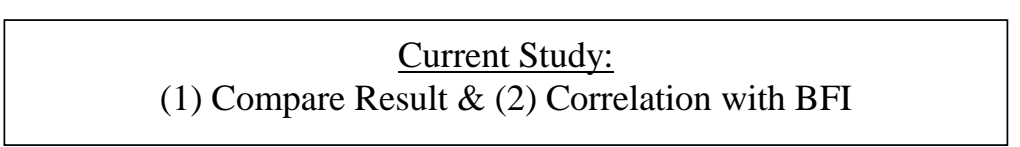

\begin{tabular}{|c|c|}
\hline $\begin{array}{l}\text { Compare Results: } \\
\text { 1. Item-total correlation } \\
\text { overall satisfying } \\
\text { 2. Five components } \\
\text { found; item structures } \\
\text { are scattered } \\
\text { 3. Data distribution were } \\
\text { not normal }\end{array}$ & $\begin{array}{l}\text { Correlation: } \\
\text { There were significant (but } \\
\text { weak) positive correlation } \\
\text { between FLL and BFI (all } \\
\text { but Receiving Gift and } \\
\text { Neuroticism) }\end{array}$ \\
\hline
\end{tabular}

Figure 4. Current study's relation with previous research.

(This study is closely related to previous research. The authors researcher tested the validity by observing the item-total correlation in each component. After that, the authors researchers compared the results of factor analysis. Finally, the analysis is done by conducting a correlation test between FLL and BFI.)

pected to be traced in future research and their impact on factor analysis results.

The result of factor analysis (as shown in Table 6) also indicates that this study is not similar to findings obtained by Surijah and Septiarly (2016). The seventeen assumed to be the valid items are no longer found in similar structures in this study. The difference between these two test results means that attempts to obtain convergent empirical evidence to support the validity of the FLL construct have not produced satisfactory results. Also, the different results from factor analysis and Cronbach's alpha values should be noted. The discrepancy in the findings of these results was one of the proofs that the use of Cronbach's alpha or factor analysis in the validation attempt of a measuring instrument is not an adequate approach.

The value of Cronbach's Alpha is often mistakenly regarded as an indication of unidimensionality (Panayides, 2013). The high Cronbach's alpha value $(>.800)$ is often assumed to indicate the unidimensionality of a cone and is associated with a strong item-total correlation as well. However, Cronbach's alpha is incapable of satisfying both assumptions. High Cronbach's alpha value does not necessarily reflect the quality of a suitable measuring instrument. The value of Cronbach's alpha may be achieved by increasing the number of items or using redundant or repeated item statements.

For example, in a previous study by Surijah and Septiarly (2016), the reliability coefficient (Cronbach's alpha) of Words of Affirmation component was $\alpha=.727$. In the current study, the value of the alpha coefficient for the same aspect is .644. However, the factor analysis showed that the items of the component were no longer in the same group. This reinforces the need for convergence of factor analysis findings and alpha values to validate a construct.

The main conclusion according to the purpose of current research is the correlation between FLL and BFI. The results showed a significant correlation between the two variables except on two aspects of Receiving Gift and Neuroticism. One of the interesting findings is on the Extraversion aspect that correlates with Words of Affirmation and Physical Touch.

Individuals classified as 'extraversion' are believed to have better interpersonal communication skills (Duffy \& Chartrand, 2015). Extraversion (or extroversion) is also found to be correlated with affection and pleasure (Paulsel \& Mottet, 2004). Extraversion is closely related to the formation of interpersonal relationships as well as verbal aspects in the interaction between humans. Words of Affirmation is a language aspect of love that is closely related to verbal 
communication. Praise and positive comments are the main things for individuals with this love language. This explains why extraversion positively correlates with aspects of the love language associated with verbal elements.

Extraversion is also significantly related to Physical Touch. Individuals with this type of love language feel loved by a physical touch like a hug or caress. Compared to other types of love languages, Physical Touch is the most intensive love language and involves direct physical contact. This explains why extrovert individuals are correlated with interpersonal communication motives such as pleasure and affection.

Paulsel and Mottet (2004) also found that in contrast to Extraversion, individuals belonging to Neuroticism are negatively correlated with aspects of pleasure and affection. Neuroticism correlates with control (self-control) and escape (avoiding interpersonal communication). This is in line with Neuroticism which is not at all correlated with the FLL aspects. Individuals belonging to the category of Neuroticism avoid intimate relationships or control themselves from feeling loved for the treatment they receive.

The lack of correlation between Neuroticism and these aspects of love language can also clarify why this aspect of BFI is negatively correlated with relationship satisfaction. Couples who report themselves as belonging to the Neuroticism category also have low marital and sexual satisfaction (Fisher \& McNulty, 2008). This finding also serves as a bridge that hypothetical love is related to the marital satisfaction or relationship quality.

Receiving Gift that does not correlate with any aspect of BFI and has the lowest R square coefficient (along with Acts of Service) becomes the basis that more in-depth study is needed in future research. This is not separated from the purpose of correlation testing as an effort to validate the FLL against external criteria.

Conscientiousness has long been believed to be an individual characteristic of success in many fields. Academic success, work, and including marriage are thought to be associated with these personality characteristics. Conscientious individuals are well-planned individuals, impulse controls, setting goals, and achieving the stated goals (Baker \& McNulty, 2011). This means individuals with this type of personality will make efforts that can maintain the quality of a relationship.

In this study, Conscientiousness is positively correlated with Quality Time. Time elements (taking time for family) are closely related or determine the level of stress in the family and marital satisfaction (Allen et al., 2000; van Steenbergen, Kluwer, \& Karney, 2014). Individuals belonging to the Conscientiousness category value their time together with their partner. Quality time spent with a partner is one important factor in the sustainability of a relationship.

Other interesting findings is the correlation between FLL and BFI. For example, agreeable and openness to experience individuals correlated with the other four aspects of FLL. It is hypothetically related to agreeable individual characters easily carrying sympathy (Rothmann \& Coetzer, 2003) making it easy to feel love for the various treatments received from their partners. Individuals who are open to new experiences will also tend to be open to experiences such as getting rewards to spending spare time with a partner.

These findings cannot fully explain the understanding of the relationship between the language of love and the personality model. The results of regression analysis showed that other factors can account for the interaction between the two variables. Costa and McCrae (1995) write in his research related to the big five personality model that the big five model is a comprehensive model. Variations of personality types fall into the combination between the five personality types or uncategorized trait types. Based on that understanding, the absence of a correlation between Receiving Gift and BFI or between Neuroticism and FLL is hypothetically due to other personality types associated with the language type of love.

Costa and McCrae's explanation of the personality model can also be analogized to the language of love that there is a possibility of a different kind of love language beyond that expressed by Chapman. These findings increasingly encourage the need for more contextual research in the sample population. Surijah and Septiarly (2016) discussed the need to conduct qualitative research that takes into account the cultural elements of the response given by the sample or resource persons. Soelaeman (1987) in his book once wrote a stereotype of the Eastern culture in Indonesia which tends to "accept." That is, when associated with feelings of being loved, if someone has a Physical Touch love language but gets treated rewarded by her partner, the individual will "accept" the treatment and feel loved. This opinion is certainly worth examining as a more modern research such as BFI mapping conducted in 56 countries around the world; the research shows that 


\begin{tabular}{|cc|}
\hline I am very happy when my boy or girlfriend hugged me & 100 \\
indifferent & feel very loved \\
& Sample \\
$n=400$ & \\
\hline
\end{tabular}

Figure 5. Scale with wider range than Likert scale standard.

(One of the authors' researchers' ideas is to use a wider range than the Likert scale standard consisting of 5 choices (Strongly Disagree- Disagree-Doubt-Agree-Strongly Agree).)

nations in the Southeast Asian region have a degree of "Agreeableness" which is more or less equal to those of nations in North America and the Middle East (Schmitt et al., 2007).

One other point of discussion is regarding the Acts of Service component. In Table 3, it can be seen that the Acts of Service aspect has the lowest average and the lowest value $\left(X_{\min }=10\right)$ when compared with other aspects. The result of factor analysis also indicates that Acts of Service items are also scattered in the various components of the findings.

According to Alvarez and Van Leuween (2014), getting help pose a psychological hazard. Conversely, giving help has a positive impact such as an increase in self-competence. Deelstra et al. (2003) reveal that aid received may be perceived as an attack on self-esteem. Help can be defined as dependencies and restrictions on choice and freedom. Assistance provided is often also considered inappropriate or unsuitable by beneficiaries.

Regarding the Acts of Service and feelings of being loved, one can feel uncomfortable or depressed when getting help from a partner. This means that the feelings experienced are counter-productive to feelings of being loved. Accepting help is deemed to weaken or make the recipient feel helpless. Also, the aid received may also not necessarily match the expected by the couple, so it creates a negative reaction compared with feelings of being loved. This can be one of the factors that moderate the findings on the Acts of Service component.

Other observational results consistently found from previous studies are abnormal data distribution (see Figure 3) because even though the individual has a certain love language but if given the expression of another love, the person could have felt loved so that the results of sample measurements on each aspect of Five Love Languages tend to be high or very high. Therefore, the five-point Likert Scale is not necessarily sensitive enough to measure how far it feels or does not feel loved, so it may take another approach example increasing the range from five points to 10 points on the Likert Scale to improve the Five Love Languages Scale capability to determine the level difference the language of love between individuals, or by using other forms of scale such as Continous Rating Scale (CRS).

Continuous Rating Scale (CRS) is a scale designed by Stanley and Jenkins (as cited in Treiblmaier \& Filzmoser, 2009). According to Brace (as mentioned in Treiblmaier \& Filzmoser, 2009), CRS is also often referred to as a graphic scale and is represented by a line between the lowest value point and the highest value point. Continuous Rating Scale is a scale that is still rarely used, but this scale has advantages. According to Lange and Söderlund (2004), the first adventage of CRS is to have good discrimination and reliability in the form of longer value ranges. The second advantage is in the use of CRS; this method can serve as "Cognitive Speed Bump." That is, the use of this scale forces respondents to think more carefully about the item and how to respond. However, in fact, Lampert (as cited in Lange \& Söderlund, 2004) found that CRS is considered the most difficult scale to be filled by respondents. This is due to the Likert scale; respondents are given a definite answer option between 1 and 5. While on CRS, the respondents were asked to put the response itself on a continuum.

Authors are of the opinion that, by increasing the range of responses and changing the range from between Strongly Disagree to Strongly Agree as the degree people feel loved, the modification can show more significantly the preferences of the respondents, compared to the present scale. Figure 5 provides an example of the use of the CRS as intended by the authors.

\section{Limitations and Research Suggestions}

As an effort to replicate previous research, the selection of research samples and the use of data 
collection tools was attempted to resemble previous research. Therefore, generalizing the results of this study to the wider population should pay attention to the limitations of the scope of the study. Another limitation encountered is the selection of external variables (BFI) is not based on the theoretical relationship (hypothetical) so that it can affect the relationship between FLL and BFI. Further research development is needed to understand these constructs better.

For further research, several suggestions can be taken:

(1) Further research may consider improvements to the measurement scale used such as adapting the scale employed by Egbert and Polk (2006) or using the CRS approach model. This modification is expected to help sample responses become more accurate and can distinguish the typical love language that is owned by each;

(2) Research in a wider population and descripttive research can be the next stage for FLL related research.

(3) A study of cultural factors or a more contextual search for the language of love is required. Research with a qualitative approach will be able to enrich understanding of FLL.

\section{Conclusion}

Five Love Languages construct validation attempts have not found convergent results compared to a previous study (Surijah \& Septiarly, 2016). Items of the components of the love language were randomly distributed outside the initial layout/ blueprint This encourages the need for validation efforts by improving elements on the measurement scale such as using the Continuous Rating Scale. However, the language of love as a construct has the external validity criteria with the personality model. The FLL scale is positively correlated to BFI except for Receiving Gift and Neuroticism aspects. This study is also able to deepen the understanding of the measurement of love language such as the distribution of data categories consistent skewed to the left. Latest modified scale also has not been able to determine a particular love language that is dominantly owned by individuals.

One of the goals of this study of love languages is to find valid theories that can help couples understand their needs in a relationship. For example, Polk and Egbert (2013) in their research in the United States have researched couples who have different types of love language. However, the findings of this study indicate the need for more in-depth study by improving the FLL measurement method to an inductive approach in FLL-related research. The inductive approach in question is that the authors take the qualitative data from the participants. The data are then analyzed to construct contextual language theories of love based on the data.

\section{References}

Allen, T. D., Herst, D. E., Bruck, C. S., \& Sutton, M. (2000). Consequences associated with work-tofamily conflict: A review and agenda for future research. Journal of Occupational Health Psychology, 5(2), 278-308.

Alvarez, K., \& van Leuween, E. (2014). Paying it forward: How helping others can reduce the psychological threat of receiving help. Journal of Applied Social Psychology, 45(1), 1-9.

Axelrod, R. (2005). Advancing the art of simulation in the social science. In Handbook of Research on Nature Inspired Computing for Economy and Management (pp. 90-100), J. Rennard (Ed.). Hersey, PA: Idea Group.

Azwar, S. (2013). Penyusunan skala psikologi. Yogyakarta: Pustaka Pelajar.

Bakker, A. B., Van Der Zee, K. I., Lewig, K. A., \& Dollard, M. F. (2010). The relationship between the big five personality factors and burnout: A study among volunteer counselors. The Journal of Social Psychology, 146(1), 31-50. https://doi.org/ 10.3200/SOCP.146.1.31-50.

Baker, L., \& McNulty, J. K. (2011). Self-Compassion and Relationship Maintenance: The Moderating Roles of Conscientiousness and Gender. Journal of Personality and Social Psychology, 100(5), 853-873.

Boyle, G. J. (2008). Critique of the five-factor model of personality. Retrieved June 11, 2017, from http://epublications.bond.edu.au/cgi/viewcontent. cgi? article $=1308 \&$ context=hss_pubs

Chapman, G. (2010). The 5 love languages: The secret to love that lasts. Chicago, IL: Northfield Pub.

Cook, M. Pasley, J., Pellarin, E., Medow, K., Baltz, M., \& Buhman-Wiggs, A. (2013). Construct validation of the five love languages. Journal of Psychological Inquiry, 18(2), 50-61.

Costa, P. T., \& McCrae, R. R. (1995). Solid grounds in the wetlands of personality: A reply to Block. Psychological Bulletin, 117, 216-220. 
Deelstra, J. T., Peeters, M. C. W., Schaufeli, W. B., Stroebe, W., Zijlstra, F. R., \& van Doormen, L. P. (2003). Receiving instrumental support at work: When help is not welcome. Journal of Applied Psychology, 88(2), 324-331.

Duffy, K. A. \& Chartrand, T. L. (2015). The extravert advantage: How and when extraverts build rapport with other people. Psychological Science, 26(11), 1795-1802.

Egbert, N., \& Polk, D. (2006). Speaking the language of relational maintenance: A validity test of Chapman's (1992) five love languages. Communication Research Reports, 23(1), 19-26.

Engmann, S., \& Cousineau, D. (2011). Comparing distributions: The two-sample Anderson-Darling test as an alternative to the Kolmogorov-Smirnoff test. Journal of Applied Quantitative Methods, 6 (3), 1-17.

Fisher, T. D., \& McNulty, J. K. (2008). Neuroticism and marital satisfaction: The mediating role played by the sexual relationship. Journal of Family Psychology, 22(1), 112-122.

Friedman, S., \& Schustack, W. (2008). Kepribadian: Teori klasik dan riset modern (3rd. ed., Vol. 1, B. Widyasinta, Trans.). Jakarta: Erlangga.

Hahn, H. A. (2013). The conundrum of verification and validation of social science-based models. Procedia Computer Science, 16, 878-887.

John, O. P., \& Srivastava, S. (1999). The big five trait taxonomy: History, measurement, and theoretical perspective.In L. A. Pervin \& O. P. John (Eds.), Handbook of personality: Theory and research (2nd. ed., pp. 102-138). New York: Guilford.

Lange, F., \& Söderlund, M. (2004). Response formats in questionnaires: Itemized rating scales versus continous rating scales. Retrieved June 5, 2016 from http://www.academia.edu/18799605/Resp onse_formats_in_questionnaires_Itemized_rating _scales_versus_continuous_rating_scales

Macal, C. M., \& North, M. J. (2007). Validation of an agent-based model of deregulated electric power markets. Retrieved June 10, 2017, from http:// www2.econ.iastate.edu/tesfatsi/EmpValidACE.M acalNorth.ElectricPower.pdf

Norman, G. (2010). Likert scales, levels of measurement and the "laws" of statistics. Advances in Health Sciences Education: Theory and Practice, 15(5), 625-632.

O'Connor, B. P. (2002). A quantitative review of the comprehensiveness of the five-factor model in relation to popular personality inventories. Assessment, 9(2), 188-203.

Panayides, P. (2013). Coefficient alpha: Interpret with caution. Europe's Journal of Psychology, 9(4), 687-696.

Paulsel, M. L., \& Mottet, T. P. (2004). Interpersonal communication motives: A communibiological perspective. Communication Quarterly, 52(2), 182195.

Pervin, L. A., Cervone, D., \& John, O. P. (2005). Personality: Theory and research (9th. ed.). New York: John Wiley \& Sons.

Polk, D. M., \& Egbert, N. (2013). Speaking the language of love: On whether Chapman's (1992) claims stand up to empirical testing. The Open Communication Journal, 7, 1-11.

Rothmann, S., \& Coetzer, E. P. (2003). The big five personality dimensions and job performance. $S A$ Journal of Industrial Psychology, 29(1), 68-74.

Schmitt, D. P., Allik, J. McCrae, R. R., \& BenetMartínez, V. (2007). Journal of Cross-Cultural Psychology, 38(2), 173-212.

Senger, Ö., \& Çelik, A. K. (2013). A Monte Carlo simulation study for Kolmogorov-Smirnov twosample test under the precondition of heterogeneity: Upon the changes on the probabilities of statistical power and type I error rates with respect to skewness measure. Journal of Statistical and Econometric Methods, 2(4), 1-16.

Soelaeman, M. M. (1987). Ilmu budaya dasar suatu pengantar. Bandung: PT. Refika Aditama.

Surijah, E. A., \& Septiarly, Y. L. (2016). Construct validation of five love languages. Anima Indonesian Psychological Journal, 31(2), 65-76.

Surijah, E. A., \& Sia, T. (2007). Mahasiswa versus tugas: Prokrastinasi akademik dan conscientiousness. Anima Indonesian Psychological Journal, 22(4), 352-374.

Towler, A. J., \& Dipboye, R. L. (2003). Development of a learning style orientation measure. Organizational Research Methods, 6(2), 216-235.

Treiblmaier, H., \& Filzmoser, P. (2009). Benefits from using continous rating scales in online survey research. Retrieved June 5, 2016 from http:// www.statistik.tuwien.ac.at/forschung/SM/SM-2 009-4complete.pdf

Van Steenbergen, E. F., Kluwer, E. S., \& Karney, B. R. (2014). Work-family enrichment, work-family conflict, and marital satisfaction: A dyadic analysis. Journal of Occupational Health Psychology, 19(2), 182-194. 